\title{
A 6.6-kV Transformerless Cascade PWM STATCOM
}

\author{
_Experimental Verification by a Three-phase 200-V, 10-kVA Laboratory System-
}

\author{
Tsurugi Yoshii Student Member (Tokyo Institute of Technology) \\ Shigenori Inoue Student Member (Tokyo Institute of Technology) \\ Hirofumi Akagi Member (Tokyo Institute of Technology)
}

Keywords: cascade STATCOM, multilevel converter, reactive power, voltage-balancing control

Attention has been paid to a multilevel converter cascading multiple single-phase H-bridge converters in each phase. Its outputvoltage level can be increased more easily than that of a diodeclamped multilevel converter. However, when the multilevel converter is applied to a cascade STATCOM, each cascaded H-bridge converter should be equipped with an isolated and split dc capacitor without any power source or circuit. Cascade STATCOMs can be classified into staircase modulation and pulse-width modulation (PWM) in terms of voltage regulation. PWM is superior in dynamic performance to, more robust against line disturbances and faults than, staircase modulation. However, no papers have proposed and experimentally verified a viable and effective control method to regulate and balance all the dc mean voltages from a practical point of view.

This paper deals with a 6.6-kV cascade PWM STATCOM with star-configuration, and proposes a control method capable of regulating reactive power and balancing all the dc capacitor voltages at the same time. Experiments based on a laboratory model confirm the effectiveness of the proposed control method. Fig. 1 shows the

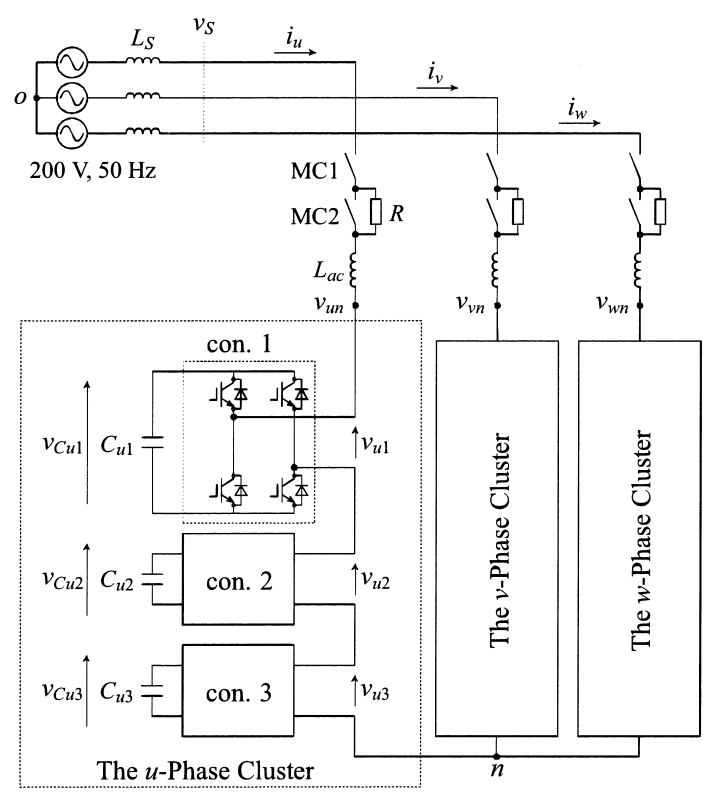

Fig. 1. Laboratory model of the three-phase 200-V, 10kVA cascaded PWM STATCOM
200-V, 10-kVA laboratory model cascading three H-bridge PWM converters in each phase. Table 1 summarizes the circuit parameters of Fig. 1. Each H-bridge converter has an isolated dc capacitor without external circuit nor power supply except for a Hall-effect voltage sensor.

Fig. 2 shows experimental waveform in a transient state from inductive to capacitive operation with a ramp change in $q^{*}$ from $-10 \mathrm{kVA}$ to $10 \mathrm{kVA}$. Although $v_{C}$ represents the nine dc-capacitor voltages, it is difficult to distinguish the nine waveforms from Fig. 2. Each dc voltage contained a $100-\mathrm{Hz}$ component inherent in a singlephase H-bridge converter, whereas each dc mean voltage was kept balanced and controlled, not only in the steady state but in the transient state. The $u$-phase ac current flowing into the STATCOM, $i_{u}$ was slightly distorted with a current THD (total harmonic distortion) of $3.7 \%$ due to a non-negligible voltage drop of IGBTs used in the down-scaled model.

Table 1. Circuit constants and control parameters in Fig. 1

\begin{tabular}{|lc||c|}
\hline Rated reactive power & $Q$ & $10 \mathrm{kVA}$ \\
\hline Nominal line-to-line rms voltage & $V_{S}$ & $200 \mathrm{~V}$ \\
\hline Background system inductance & $L_{S}$ & $48 \mu \mathrm{H}(0.4 \%)$ \\
\hline AC link inductor & $L_{a c}$ & $1.2 \mathrm{mH}(10 \%)$ \\
\hline Starting resistor & $R$ & $10 \Omega$ \\
\hline DC capacitor voltage & $v_{C}$ & $60 \sim 70 \mathrm{~V}$ \\
\hline DC capacitors & $C$ & $16,400 \mu \mathrm{F}$ \\
\hline Unit capacitance constant & $H$ & $36 \mathrm{~ms}(70 \mathrm{~V})$ \\
\hline Carrier frequency for PWM & & $1 \mathrm{kHz}$ \\
\hline
\end{tabular}
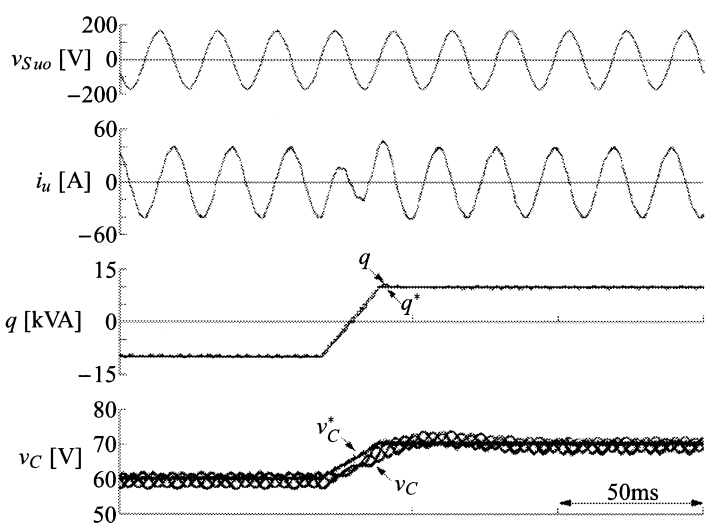

Fig. 2. Experimental waveforms in a transient state from inductive to capacitive operation at $10 \mathrm{kVA}$. 


\section{$6.6 \mathrm{kV}$ トランスレス・カスケードPWM STATCOM}

一三相 $200 \mathrm{~V} 10 \mathrm{kVA}$ ミニモデルによる動作検証一

学生員 吉井 剣* 学生員 井上 重德*

正 員 赤木 泰文*

\section{A 6.6-kV Transformerless Cascade PWM STATCOM}

_Experimental Verification by a Three-phase 200-V, 10-kVA Laboratory System-

Tsurugi Yoshii*, Student Member, Shigenori Inoue*, Student Member, Hirofumi Akagi*, Member

This paper deals with a 6.6-kV transformerless STATCOM cascading multiple single-phase H-bridge PWM converters in each phase. The ac voltage of the STATCOM is almost sinusoidal, so that it requires no harmonic filter. Each converter is equipped with a capacitor and a voltage sensor on the dc side, which are electrically isolated from each other. The STATCOM has the capability of self-starting and voltage-balancing without any external power supply or equipment. Experiment by a three-phase $200-\mathrm{V}, 10-\mathrm{kVA}$ laboratry system, along with computer simulation, is carried out to confirm the viability and effectiveness of the STATCOM.

キーワード : カスケード STATCOM, マルチレベル変換器, 無効電力, 電圧バランス制御

Keywords: cascade STATCOM, multilevel converter, reactive power, voltage-balancing control

\section{1. まえがき}

近年，無効電力を連続的に制御できる自励式無効電力補 償装置 (STATCOM) が注目されている。系統連系用変圧器 はSTATCOM の体積・重量の増加を招き, 例えば $6.6 \mathrm{kV}$, $1 \mathrm{MVA}$ の変圧器の重量は $3000 \mathrm{~kg}$ から $4000 \mathrm{~kg}$ に達する。 したがって，マルチレベル変換器をベースとしたトランス レス STATCOM が望ましい。単相電圧形コンバータをカス

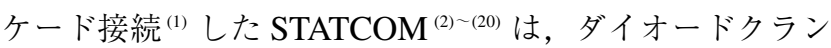
プ形コンバータを使用したSTATCOM ${ }^{(21)}$ に比べて段数の 拡張が容易である。しかし, 多数の独立した直流コンデン サの電圧不均一抑制することが難しい。

カスケード STATCOM の変調方式は, 階段状の電圧を出 力する階段波変調 (2)(3)(12)(19)（staircase modulation）を用いた 方式と PWM 方式に分類できる。PWM 方式は応答速度や 系統の擾乱，地絡事故に対する安定性の点で有利であり， 国内外で活発に研究されている(5) (9)(12)(15)(18)(20)。しかし, 起 動時の挙動も考慮し, かつ段数の拡張にも容易に対応でき る直流電圧バランス制御法は確立されていないように思わ

\footnotetext{
* 東京工業大学 大学院理工学研究科電気電子工学専攻

T 152-8552 東京都目黒区大岡山 2-12-1, S3-17

Department of Electrical and Electronic Engineering,

Tokyo Institute of Technology

S3-17, 2-12-1, O-okayama, Meguro, Tokyo 152-8552
}

れる。

本論文は図 1 に示す $6.6 \mathrm{kV}$ 配電系統に設置するカスケー ド PWM STATCOM を対象とする。同一回路構成の単相電 圧形PWM コンバータを 1 相あたり 6 段カスケード接続し ている。この場合, 各直流コンデンサ電圧は $1 \mathrm{kV}$ に設定で きるため $1.7 \mathrm{kV}$ IGBT を使用できる。この $1.7 \mathrm{kV} \mathrm{IGBT} \mathrm{は}$ 3.3/4.5/6.5 kV IGBT に比べてスイッチング損失が低く, し かも流通量が多いためにコスト的にも有利である。各コン バータの直流側には初期充電回路や電圧バランス回路など の外部回路を必要としない。本論文で提案する直流電圧バ ランス制御法は，相間バランス制御と段間バランス制御か ら構成されている点に特長がある。さらに本論文では, 三 相 $200 \mathrm{~V}$ 10kVA のミニモデルを設計・製作し, 無効電力制 御と直流電圧の不均一抑制が同時にできることを実験的に 検証する。

\section{2. ミニモデルのシステム構成}

図 2 に実験に用いたミニモデルの回路構成を, 表 1 に回 路・制御定数を示す。1 相あたり単相電圧形PWM コンバー 夕を 3 段カスケード接続している。各コンデンサには直流 電圧検出器を接続しているが, 起動や電圧不均一抑制を目 的とした外部回路は接続していない。起動回路はコンタク 夕 $\mathrm{MC} 1, \mathrm{MC} 2$ と電流制限抵抗 $R$ から構成されている。 $L_{S}$ は実験室の $200 \mathrm{~V}$ 配電盤の上位インダクタンスを実測した 


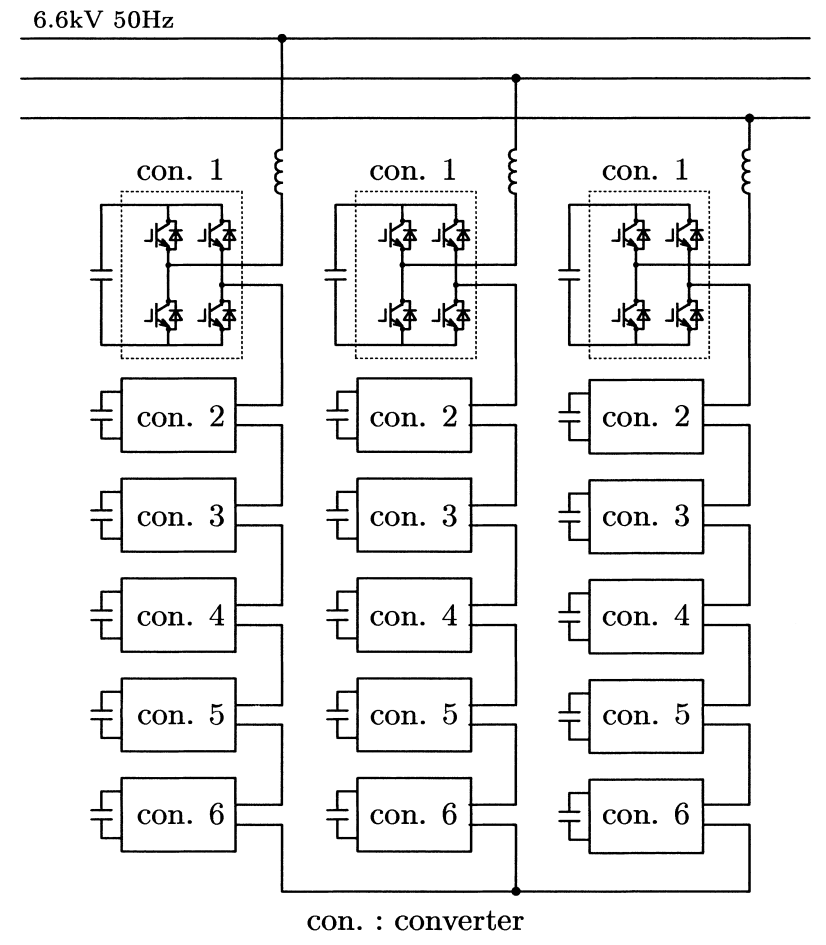

図 $11.7 \mathrm{kV}$ IGBT を使用した $6.6 \mathrm{kV}$ トランスレス・ カスケード PWM STATCOM の主回路構成

Fig. 1. Circuit of the 6.6-kV cascade PWM STATCOM using 1.7-kV IGBTs.

表 1 図 2 の回路定数と制御定数

Table 1. Circuit constants and control parameters in Fig. 2

\begin{tabular}{|lc||c|}
\hline Rated reactive power & $Q$ & $10 \mathrm{kVA}$ \\
\hline Nominal line-to-line rms voltage & $V_{S}$ & $200 \mathrm{~V}$ \\
\hline Background system inductance & $L_{S}$ & $48 \mu \mathrm{H}(0.4 \%)$ \\
\hline AC link inductor & $L_{a c}$ & $1.2 \mathrm{mH}(10 \%)$ \\
\hline Starting resistor & $R$ & $10 \Omega$ \\
\hline DC capacitor voltage & $v_{C}$ & $60 \sim 70 \mathrm{~V}$ \\
\hline DC capacitors & $C$ & $16,400 \mu \mathrm{F}$ \\
\hline Unit capacitance constant & $H$ & $36 \mathrm{~ms}(70 \mathrm{~V})$ \\
\hline Carrier frequency for PWM & & $1 \mathrm{kHz}$ \\
\hline Low-pass-filter cut-off frequency & & $15 \mathrm{~Hz}$ \\
\hline Dead time & $2 \mu \mathrm{s}$ \\
\hline
\end{tabular}

\section{ものである。}

図 3 に示すように, DSP·FPGA をべースにした全ディジ タル制御システムを採用している。図 4 に示すように, 3 段 の単相電圧形 PWM コンバータの三角波キャリア $(1 \mathrm{kHz})$ は互いに 120 度の位相差を有し，等価スイッチング周波数 はキャリア周波数の 6 倍 $(6 \mathrm{kHz})$ となる。サンプリングは 三角波キャリアの頂点で行い，サンプリング周期はキャリ ア周期の $1 / 6(167 \mu \mathrm{s})$ となる。指令值の変更は, マルチス イッチングを防止するために各段の三角波キャリアの頂点 で行う。したがって，更新周期は $500 \mu \mathrm{s}$ である。

\section{3. 制 御 法}

図 5 にミニモデルの制御系を示す。ディジタル PLL の

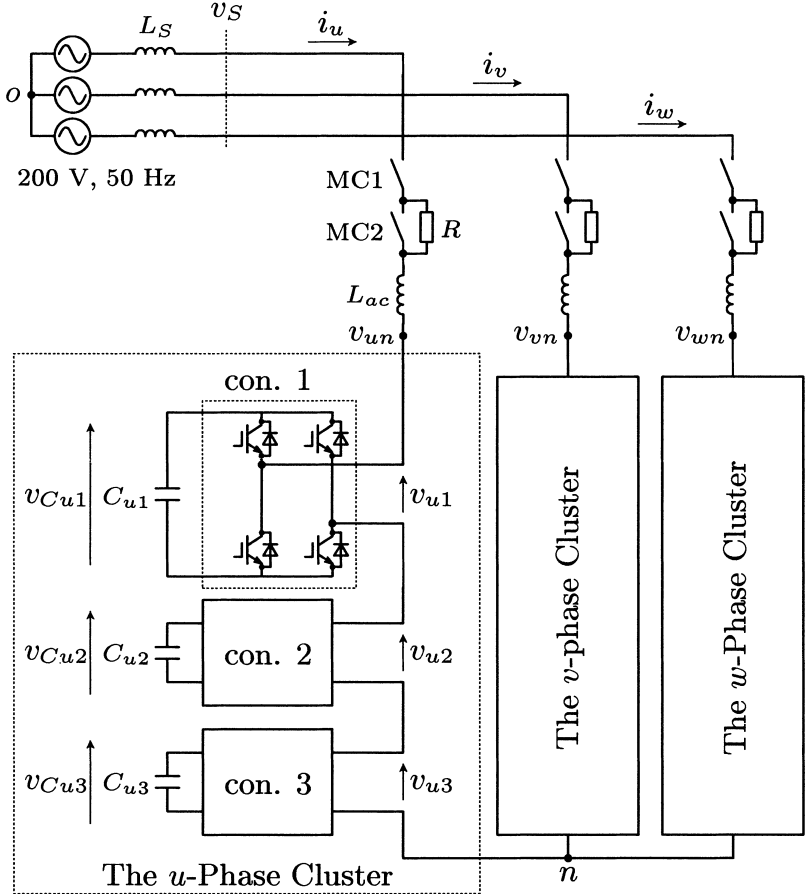

図 2 三相 $200 \mathrm{~V} 10 \mathrm{kVA}$ カスケード PWM STATCOM の実験回路

Fig. 2. Experimental circuit of the three-phase 200-V, 10-kVA cascaded PWM STATCOM.

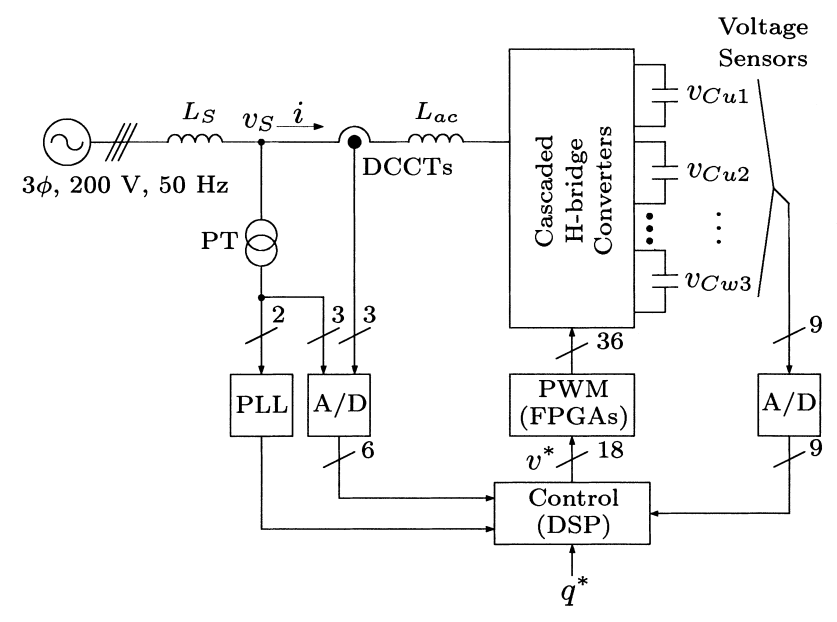

図 3 制御システム

Fig. 3. Control system.

位相基準は $u$ 相の系統相電圧

$$
v_{\text {Sиo }}=\sqrt{\frac{2}{3}} V_{S} \sin \omega t
$$

としている。

本制御系の主要部分は 3 個のブロックに分けられる。第 1 ブロックは無効電力制御と直流電圧一括制御であり, $d-q$ 変換を用いて三相を一括に扱い $d$ 軸電流と $q$ 軸電流を独立 に制御する。第 2 ブロックは相間直流電圧バランス制御で あり, 各相の直流コンデンサ電圧の平均值を相間でバラン スさせる。第 3 ブロックは段間直流電圧バランス制御であ 


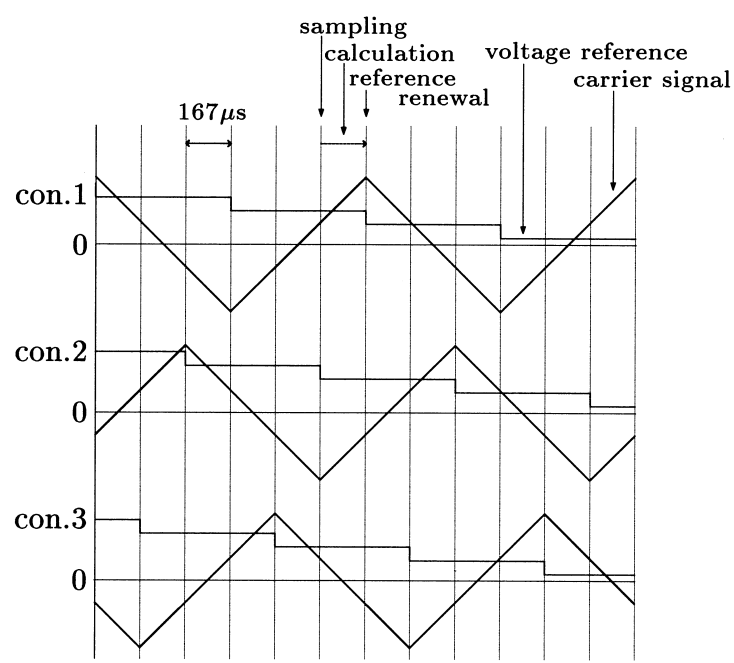

図 4 キャリア信号とサンプリングタイミング

Fig. 4. Three carrier signals with a phase shift of $2 \pi / 3$, and sampling timing.

り, 各相ごとに各段間の直流コンデンサ電圧をバランスさせ る。第 2 ブロックと第 3 ブロックを総じて直流電圧バラン ス制御と呼ぶ。本制御法はカスケード接続の段数に応じて 容易に拡張できる特長がある。図 5 において，例えば $\bar{v}_{C u 1}$ はカットオフ周波数 $15 \mathrm{~Hz}$ のローパスフィルタ $(\mathrm{LPF})$ に より $v_{C u 1}$ から $100 \mathrm{~Hz}$ のリプル成分を除去したものである。 $\bar{v}_{C}$ は全相全段の直流電圧の平均值である。

$$
\bar{v}_{C}=\frac{1}{3}\left(\bar{v}_{C u}+\bar{v}_{C v}+\bar{v}_{C w}\right) \cdot
$$

ここで，例えば $\bar{v}_{C u}$ は $u$ 相の直流電圧平均值である。

$$
\bar{v}_{C u}=\frac{1}{3}\left(\bar{v}_{C u 1}+\bar{v}_{C u 2}+\bar{v}_{C u 3}\right) \text {. }
$$

$\langle 3 \cdot 1\rangle$ 無効電力制御と直流電圧一括制御 図 6 に無 効電力制御と直流電圧一括制御のブロックを示す。図 2 の 交流側の電圧電流方程式は次式のように表される。

$$
\left[\begin{array}{c}
v_{S u o} \\
v_{S v o} \\
v_{S w o}
\end{array}\right]-\left[\begin{array}{c}
v_{u n} \\
v_{v n} \\
v_{w n}
\end{array}\right]=L_{a c} \frac{d}{d t}\left[\begin{array}{c}
i_{u} \\
i_{v} \\
i_{w}
\end{array}\right] \ldots
$$

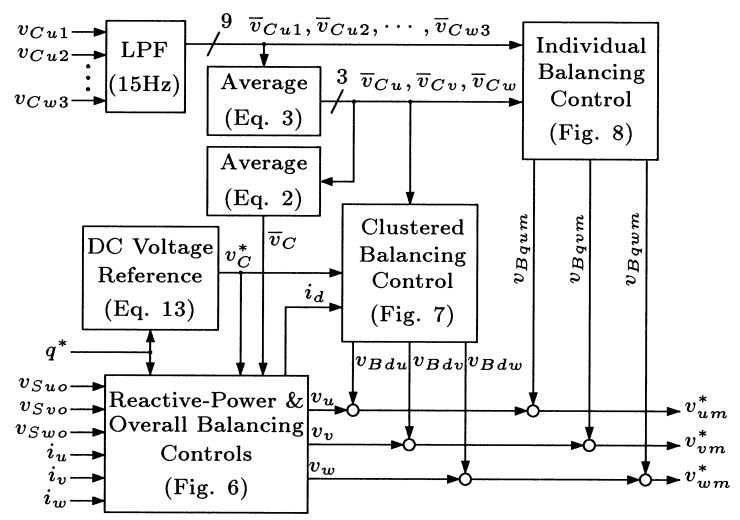

図 5 制御系のブロック図

Fig. 5. Control block diagram.
抵抗成分は十分に小さいものとして無視している。(4) 式に 三相/二相変換， $d-q$ 変換を適用すると,

$$
\left[\begin{array}{cc}
L_{a c} \frac{d}{d t} & -\omega L_{a c} \\
\omega L_{a c} & L_{a c} \frac{d}{d t}
\end{array}\right]\left[\begin{array}{l}
i_{d} \\
i_{q}
\end{array}\right]=\left[\begin{array}{l}
v_{S d}-v_{d} \\
v_{S q}-v_{q}
\end{array}\right] \ldots
$$

となる。 $v_{d}$ と $v_{q}$ は STATCOM の交流側電圧（3段分の和） の $d$ 軸, $q$ 軸成分である。電源を三相平衡正弦波電圧源と $し$, 三相座標系の $u$ 軸を回転座標系の $d$ 軸に一致させてい るので $v_{S q}=0$ となる。よって, 瞬時実電力 $p$ と瞬時虚電 力 $q$ は,

$$
\begin{aligned}
& p=v_{S d} \cdot i_{d}+v_{S q} \cdot i_{q}=v_{S d} \cdot i_{d} \ldots \ldots \ldots \ldots \ldots \ldots \\
& q=v_{S d} \cdot i_{q}-v_{S q} \cdot i_{d}=v_{S d} \cdot i_{q} \ldots \ldots \ldots \ldots \ldots \ldots
\end{aligned}
$$

で表される。すなわち， $i_{d}, i_{q}$ を制御することにより $p, q$ は独立に制御できる。したがって, $d$ 軸電流指令值 $i_{d}^{*}$ は比 例制御を適用して以下のように与える。

$$
i_{d}^{*}=K_{1}\left(v_{C}^{*}-\bar{v}_{C}\right)
$$

ここで $v_{C}^{*}$ は直流電圧指令值である。また, $q$ 軸電流指令值 $i_{q}^{*}$ は無効電力指令值 $q^{*}$ を用いて以下の式で与える。

$$
i_{q}^{*}=\frac{q^{*}}{v_{S d}}
$$

したがって, $d$ 軸電圧指令值 $v_{d}^{*}$ と $q$ 軸指令值 $v_{q}^{*}$ を次式の ように与える。

$$
\begin{aligned}
{\left[\begin{array}{l}
v_{d}^{*} \\
v_{q}^{*}
\end{array}\right]=} & \frac{1}{3}\left(\left[\begin{array}{l}
v_{S d} \\
v_{S q}
\end{array}\right]-\left[\begin{array}{cc}
0 & -\omega L_{a c} \\
\omega L_{a c} & 0
\end{array}\right]\left[\begin{array}{l}
i_{d} \\
i_{q}
\end{array}\right]\right. \\
& \left.-K_{2}\left[\begin{array}{l}
i_{d}^{*}-i_{d} \\
i_{q}^{*}-i_{q}
\end{array}\right]-\frac{K_{2}}{T_{2}} \int\left[\begin{array}{c}
0 \\
i_{q}^{*}-i_{q}
\end{array}\right] d t\right) \ldots \ldots
\end{aligned}
$$

第一項は電源電圧を，第二項は連系リアクトル $L_{a c}$ の両端 に発生する電圧を打ち消している。第三項は $d$ 軸電流と $q$ 軸電流の比例制御であり, 第四項は $q$ 軸電流の積分制御で ある。この手法は，三相 PWM コンバー夕における非干渉 電流制御を STATCOM に適用したものである ${ }^{(24)}$ 。なお， $d$ 軸電流制御については制御の安定性を重視し, 比例制御の みとした。係数の $1 / 3$ は, 電圧を 3 段の PWM コンバー夕 に分割するためのもので，さらに(10) 式を逆 $d-q$ 変換，二 相/三相変換することによって各コンバー夕共通の交流指令 值を得る。

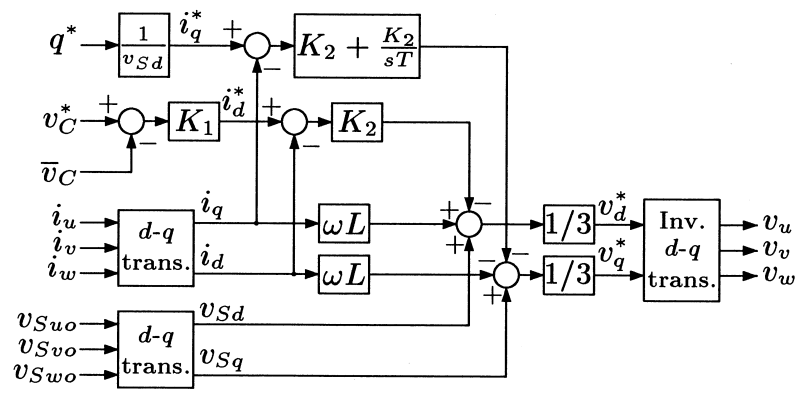

図 6 無効電力制御と直流電圧一括制御

Fig. 6. Reactive-power control and overall balancing control. 


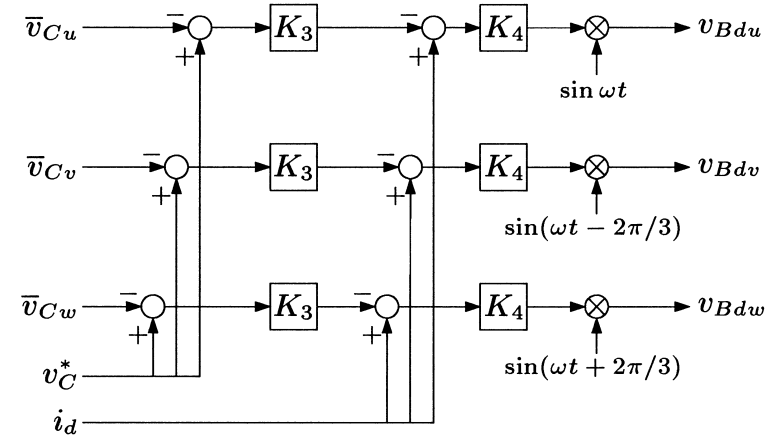

図 7 相間直流電圧バランス制御

Fig. 7. Clustered blancing control.

$\langle\mathbf{3} \cdot \mathbf{2}\rangle$ 相間直流電圧バランス制御 四 7 に相間直流 電圧バランス制御ブロックを示す。各相 3 段の直流電圧平 均値 $\bar{v}_{C u}, \bar{v}_{C v}, \bar{v}_{C w}$ を用いて, 一相あたり一台の単相 PWM コンバータとみなして制御する。以下では $u$ 相について説 明する。

基本的な考え方は, 三相 PWM コンバー夕の電流マイナー ループを有する直流電圧制御と同様である。 $d-q$ 座標系に 相当する直流座標系上で, 直流電圧の指令值と実電圧の偏 差にゲインを掛けて有効電流指令值を決定する。次に電流 制御を行い, 交流座標系に逆変換して三相の電圧指令值を 得る。すなわち, 電圧指令值 $v_{C}^{*}$ と平均直流電圧值 $\bar{v}_{C u}$ およ び $d$ 軸電流值 $i_{d}$ を用いて, 次のように電圧指令值を与える。

$$
v_{B d u}=-K_{4}\left\{K_{3}\left(v_{C}^{*}-\bar{v}_{C u}\right)-i_{d}\right\} \sin \omega t \cdot
$$

一般に，電流マイナーループを付加することは安定な電 圧制御には不可欠である。しかし，各相ごとに有効電流の 瞬時值を遅れなく得ることは不可能であり, 図 7 では $i_{d}$ で 代用している。

通常の $d$ 軸電流制御との相違点は $\bar{v}_{C u}, \bar{v}_{C v}, \bar{v}_{C w}$ を個別 に制御していることである。実際のシステムではIGBT の 損失やスイッチング特性のばらつきから，損失を補填する ための有効電流は各相間で異なる。しかし，通常の $d$ 軸電 流制御は平衡三相電圧を出力するため，このような不平衡 な有効電流を制御することはできない。本論文の相間バラ ンス制御では，上述したように「各相独立に $d$ 軸電流制御」 を行い, 基本波の零相電圧を含む不平衡三相電圧を出力す ることができる。その結果, $\bar{v}_{C u}, \bar{v}_{C v}, \bar{v}_{C w}$ はバランスする。

相間バランス制御は，(2) 式と (3) 式の平均值演算の項を 増加させるのみで，容易に段数を拡張可能である。

$\langle\mathbf{3} \cdot \mathbf{3}\rangle$ 段間直流電圧バランス制御＼cjkstart図 8 に段間直流 電圧バランス制御ブロックを示す。各コンバータにおいて 無効電流と同位相/逆位相の電圧を出力することで, 有効電 力を流入/放出させる。 $u$ 相 $m$ 段目の指令值は次のように与 える。

$$
v_{\text {Bum }}=\left\{\begin{array}{ll}
K_{5}\left(\bar{v}_{C u}-v_{C u m}\right) \cos \omega t & q^{*}>0 \\
-K_{5}\left(\bar{v}_{C u}-v_{C u m}\right) \cos \omega t & q^{*}<0
\end{array} \ldots \ldots\right.
$$

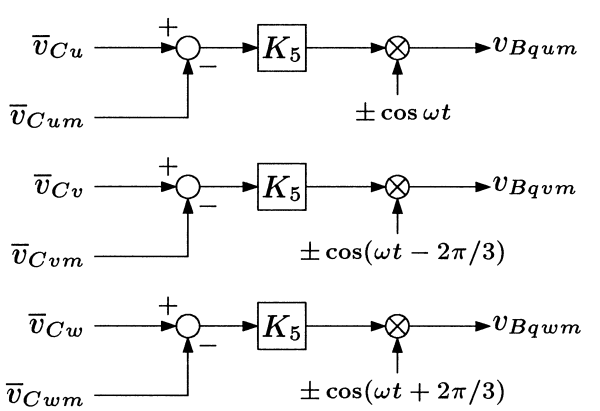

図 8 段間バランス制御（ $m$ 段目）

Fig. 8. Individual balancing control between the three cascaded converters in each cluster.

$\cos \omega t$ は電源電圧基準位相 $\sin \omega t$ に直交している。無効電 力が零の場合は段間バランス制御は作用しないため，図 2 のミニモデルにおいては, 無効電力指令值 $q^{*}<1 \mathrm{kVA}$ で段 間バランス制御を停止している。

段間バランス制御についても，段数に応じて (12) 式を追 加することで，容易に段数の拡張が可能である。

$\langle\mathbf{3 \cdot 4}$ 直流コンデンサ電圧可変制御 以上の制御と は別に, 電流 THD 低減を目的とした直流コンデンサ電圧可 変制御を採用している。変調率の低下は電圧レベル数の減 少を招くため, 変調率を一定に保つことが望ましい。STAT$\mathrm{COM}$ の出力する電圧は無効電力の大きさに比例するため, 直流コンデンサ電圧指令值 $v_{C}^{*}$ を以下のように与えること で，変調率を一定に保つことができる。

$$
\begin{aligned}
& v_{C}^{*}=65+0.5 q^{*}[\mathrm{~V}] \\
& \text { ただし, } q:[\mathrm{kVA}]
\end{aligned}
$$

\section{4. 実験結果}

〈4・1〉起動特性 図9に起動時の波形を示す。STAT$\mathrm{COM}$ 起動時は，まず全ゲートを OFF した状態で MC1 の みを閉じる。各段の PWM コンバータはダイオード整流器 として動作し, 電流制限抵抗 $R$ を経由して直流コンデンサ を充電する。時定数は $R \times C / 3=55 \mathrm{~ms}$ である。 $1 \mathrm{~s}$ 経過後 にMC2 閉じて $R$ を短絡し，スイッチングを開始する。直 流コンデンサ電圧を運転電圧まで増加させると同時に, 無 効電力の制御を開始する。図9(a) では, ダイオード整流器 として充電が行われ，MC2 を閉じた後に図 9(b)に打いて スイッチングを開始した。オーバーシュート防止のために 直流コンデンサ電圧指令值 $v_{C}^{*}$ はランプ状に変化させた。無 効電力指令值 $q^{*}$ は $10 \mathrm{kVA}$ （コンデンサ動作）である。 $v_{C}^{*}$ と同じく $q^{*}$ もランプ状に変化させ，さらに $v_{C}^{*} か ゙ ~ 60 \mathrm{~V}$ 以 下の期間は変化率を低下させてオーバーシュートを防止し た。スイッチング開始と同時に無効電力補償を開始するた め，相間直流電圧バランス制御，段間直流電圧バランス制 御ともに動作させている。したがって, 起動時においても 各直流コンデンサ電圧の不均一は抑制されている。

$\langle\mathbf{4} \cdot \mathbf{2}\rangle$ 定常時・過渡時の動作検証 困 10 では $q^{*}=$ 


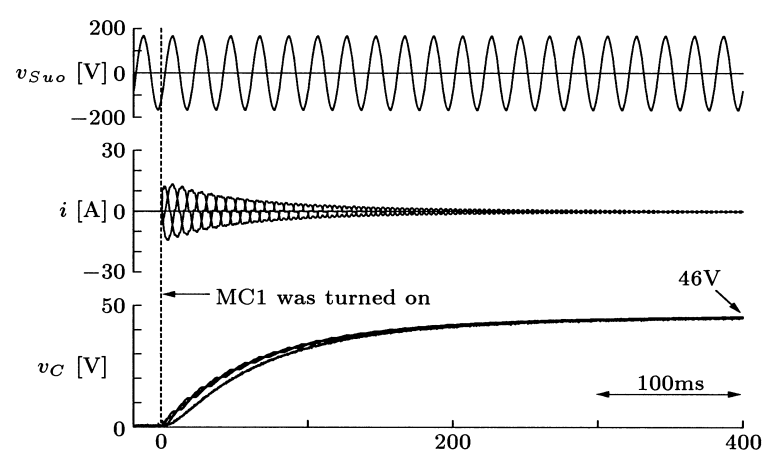

(a) $-20 \mathrm{~ms} \leq t \leq 400 \mathrm{~ms}$

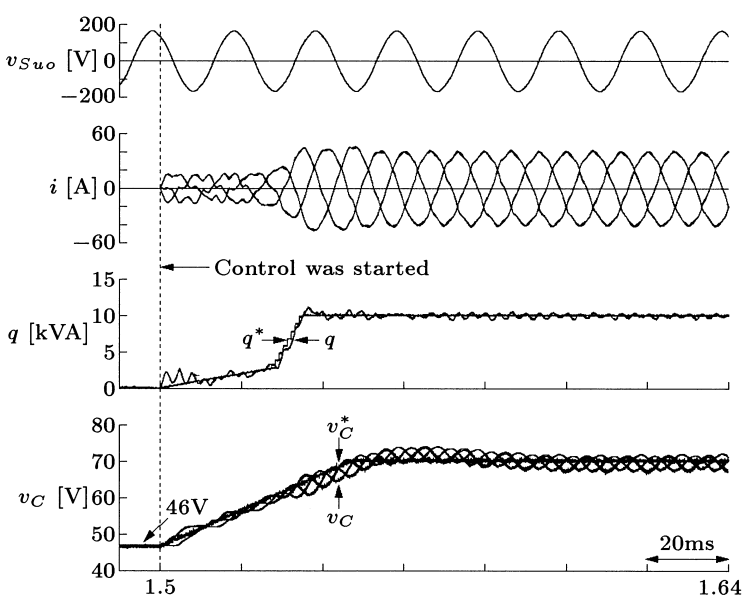

(b) $1.47 \mathrm{~s} \leq t \leq 1.64 \mathrm{~s}$

図 9 始動時の動作波形

Fig. 9. Experimental waveforms during startup.

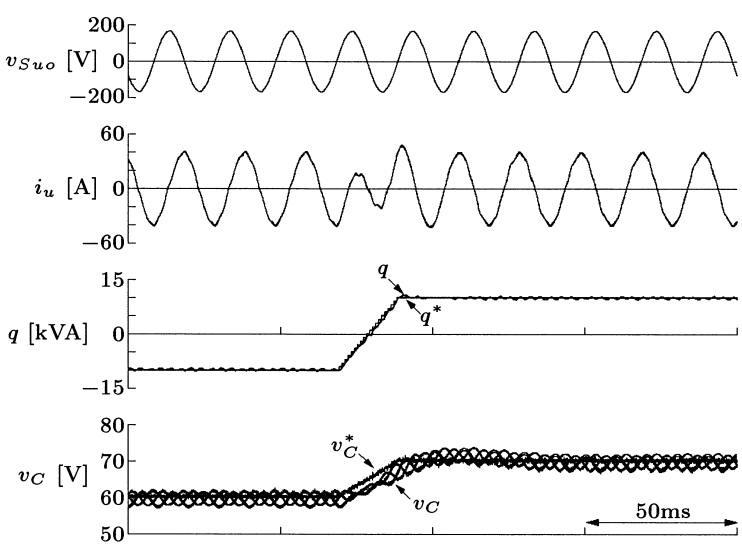

図 10 リアクトル動作からコンデンサ動作の 実験波形（10 kVA）

Fig. 10. Experimental waveforms in a transient state from inductive to capacitive operation at $10 \mathrm{kVA}$.

-10 kVA（定格リアクトル動作）から，20 ms（1 周期）で $10 \mathrm{kVA}$ (定格コンデンサ動作)に変化させた。詳細は次章に 述べるが，10kVA コンデンサ動作時の電流 THD は $3.7 \%$ で あった。無効電力 $q$ は定常時のみならず過渡時においても 指令值 $q^{*}$ に偏差なく追従した。直流コンデンサ電圧 $v_{C}$ は, 三相 3 段 9 個分を示している。定常時に扔いてはリアクト ル動作・コンデンサ動作に関わらず不均一は抑制されてお

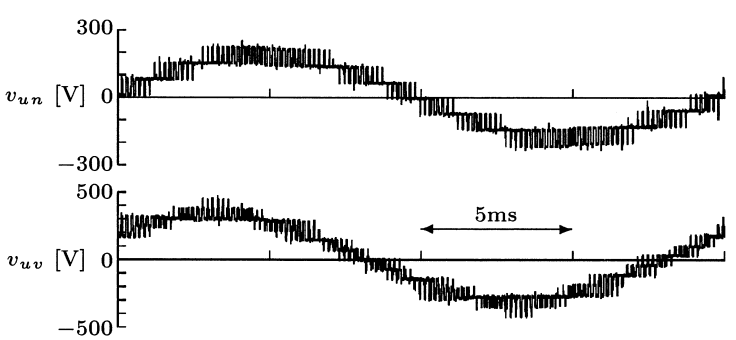

図 11 定格コンデンサ動作時の出力電圧波形 $\left(v_{C}^{*}=70 \mathrm{~V}\right)$

Fig. 11. Experimental waveforms with capacitive operation at $10 \mathrm{kVA}$ with $v_{C}^{*}=70 \mathrm{~V}$.

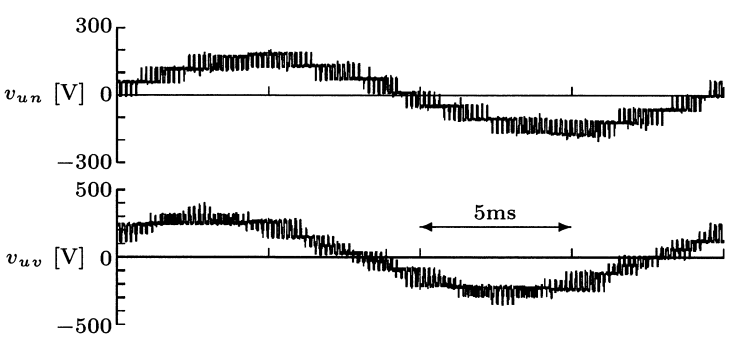

図 12 定格リアクトル動作時の出力電圧波形

$$
\left(v_{C}^{*}=60 \mathrm{~V}\right)
$$

Fig. 12. Experimental waveforms with inductive operation at $10 \mathrm{kVA}$ with $v_{C}^{*}=60 \mathrm{~V}$.

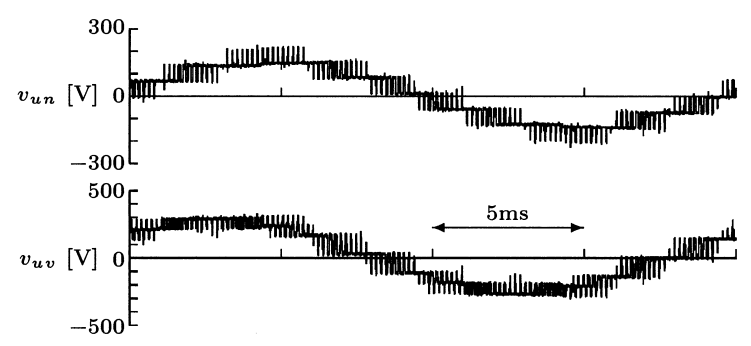

図 13 定格リアクトル動作時の出力電圧波形

$$
\left(v_{C}^{*}=70 \mathrm{~V}\right)
$$

Fig. 13. Experimental waveforms with inductive operation at $10 \mathrm{kVA}$ with $v_{C}^{*}=70 \mathrm{~V}$.

り，バランス制御が有効に作用している。過渡時において は $v_{C}^{*}$ の変化に対して $v_{C}$ の応答に遅れがあり, 約 $2 \mathrm{~V}$ ほど オーバーシュートが発生した。これは主に $v_{C} に$ 含まれる $100 \mathrm{~Hz}$ リプルの除去に用いたLPFによる制御遅れが原因 であるが，電圧不均一は生じていない。

図 11 にコンデンサ動作時, 図 12 にリアクトル動作時の 出力電圧波形をそれぞれ示す。相電圧 7 レベル, 線間電圧 13 レベルの電圧波形となっている。変調率を一定に保持す るため，リアクトル動作時に電圧レベルの減少は生じてい ない。一方, 図 13 のように直流電圧を $70 \mathrm{~V}$ 一定とすると 変調率が低下し, 線間電圧は 9 レベルまで減少した。

$\langle\mathbf{4} \cdot \mathbf{3}\rangle$ 直流電圧バランス制御の動作検証図 14 は定 格コンデンサ動作中に相間バランス制御を意図的に停止し, 3 秒経過後に再開したものである。相間バランス制御を停 止したことによって $v_{C}$ には最大 $17 \mathrm{~V}$ ほどの不均一が生じ 


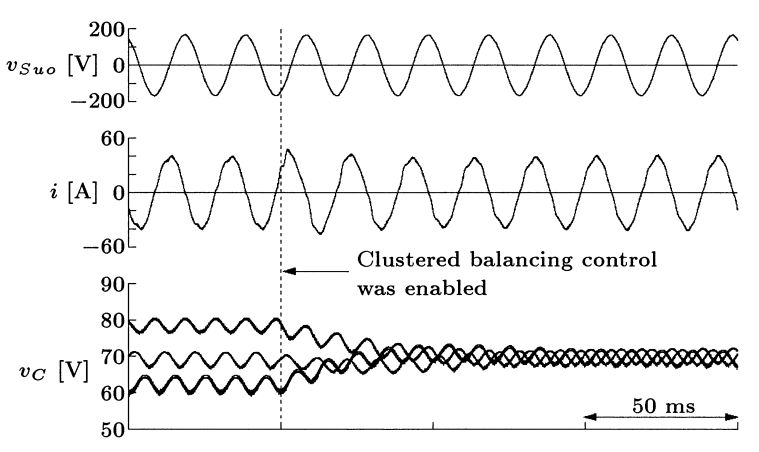

図 14 相間直流電圧バランス制御の効果

Fig. 14. Experimental waveforms confirming the effectiveness of the clustered balancing control.

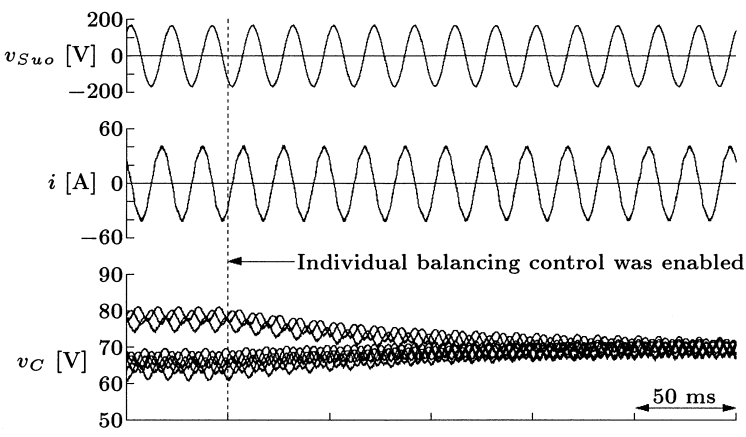

図 15 段間直流電圧バランス制御の効果

Fig. 15. Experimental waveforms confirming the effectiveness of the individual balancing control.

た。段間バランス制御は動作しているため, 各相内の各段コ ンバータには直流電圧不均一は発生していない。したがっ て不均一は相間で発生し, 直流コンデンサ電圧波形は $u$ 相, $v$ 相， $w$ 相の 3 つの集団に分散した。図中の破線の時刻にお いて制御を再開すると， $v_{C}$ は $40 \mathrm{~ms}$ ほどで指令值 $(70 \mathrm{~V})$ に収束した。

図 15 では段間バランス制御を停止し，10秒経過後に制御 を再開している。段間バランス制御を停止したことによっ て $v_{C}$ には最大 $15 \mathrm{~V}$ ぼの不均一が生じた。図中の破線の 時刻において制御を再開すると，200 ms 経過後に指令值 $(70 \mathrm{~V})$ に収束し不均一を抑制することができた。以上の結 果より，相間バランス制御と段間バランス制御の併用が有 効であることを実証した。

\section{5. 電流ひずみに関する考察}

図 16 に $10 \mathrm{kVA}$ コンデンサ動作時の波形を示す。この ときの電流 THD は $3.7 \%$ と比較的大きい。その主要な原 因の一つとして考えられるのが，IGBT の順方向電圧降下 $V_{C E(S a t)}$ 及びダイオードの順方向電圧降下 $V_{F}$ である。ミニ モデルには $600 \mathrm{~V} 150 \mathrm{~A}$ の IGBT モジュールを用いており， 電圧降下は $1.5 \mathrm{~V}$ 程度である。各相は 3 段カスケード構成 であるので， 1 相あたり $9 \mathrm{~V}(=1.5 \mathrm{~V} \times 6)$ の電圧降下を生 じる。

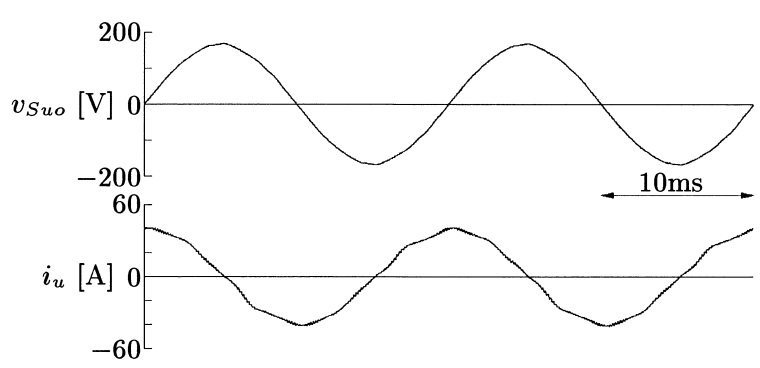

図 16 定格コンデンサ動作時の実験波形

Fig. 16. Experimental waveforms with capacitive operation at $10 \mathrm{kVA}$.

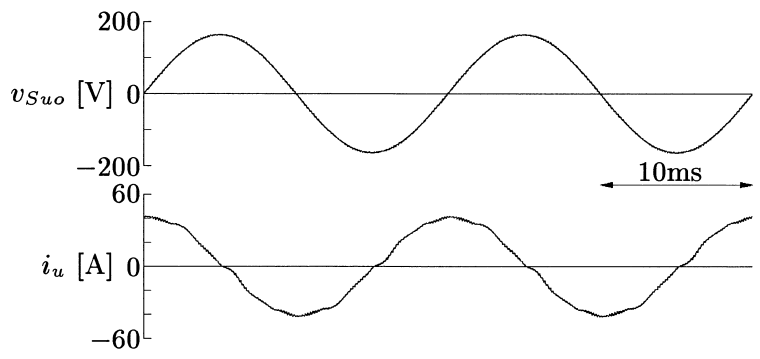

図 17 定格コンデンサ動作時のシミュレーション 波形 $\left(V_{C E(\text { Sat })}=V_{F}=1.5 \mathrm{~V}\right)$

Fig. 17. Simulated waveforms with capacitive operation at $10 \mathrm{kVA}$ with $V_{C E(S a t)}=V_{F}=1.5 \mathrm{~V}$.

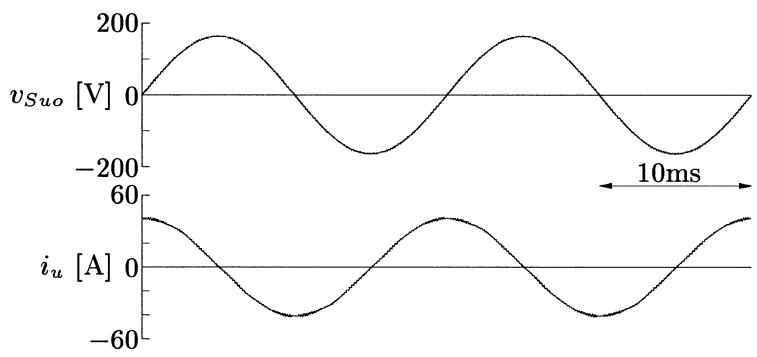

図 18 定格コンデンサ動作時のシミュレーション 波形 $\left(V_{C E(\text { Sat })}=V_{F}=0.17 \mathrm{~V}\right)$

Fig. 18. Simulated waveforms with capacitive operation at $10 \mathrm{kVA}$ with $V_{C E(S a t)}=V_{F}=0.17 \mathrm{~V}$.

図 17 に $V_{C E(\text { Sat })}=V_{F}=1.5 \mathrm{~V}$ としたときのPSCAD に よるシミュレーション結果を示す (シミュレーション I )。 図 16 の実験波形と類似した波形が得られている。

シミュレーションにはPSCAD（Manitoba 社）を使用し， 以下の点を考慮した。

・ディジタル制御による 1 サンプル遅延 $(167 \mu \mathrm{s})$

・デッドタイム $(2 \mu \mathrm{s})$

- 順方向電圧降下 $V_{C E(\text { Sat })}=V_{F}$ （一定）

・系統インダクタンス $L_{S}$

IGBT/ダイオードについては順方向電圧降下のみを考慮し, それ以外は理想スイッチとした。

$6.6 \mathrm{kV} \mathrm{STATCOM}$ を設計する際には直流電圧 $v_{C}$ を $1 \mathrm{kV}$ に設定するので，1.7 kV IGBT/ダイオードを使用した場合 
表 $210 \mathrm{kVA}$ コンデンサ動作時の電源電流高調波含有率と総合高調波ひずみ率 [\%]

Table 2. Supply harmonic currents and THD with capacitive operation at $10 \mathrm{kVA}$, expresses as [\%].

\begin{tabular}{|c||c|c|c|c|c|c|c|c|c|c|c|c|c||c|}
\hline Harmonic order & 2nd & 3rd & 4th & 5th & 6th & 7th & 8th & 9th & 10th & 11 th & 12th & 13 th & 15 th & THD \\
\hline Experiment & 1.1 & 1.4 & 0.5 & 1.9 & 0.3 & 2.3 & 0.5 & 0.6 & 0.4 & 0.8 & 0.1 & 0.5 & 0.0 & 3.7 \\
\hline Simulation I & 0.0 & 0.0 & 0.0 & 2.0 & 0.0 & 2.7 & 0.1 & 0.0 & 0.1 & 1.6 & 0.0 & 1.1 & 0.0 & 3.9 \\
\hline Simulation II & 0.0 & 0.1 & 0.0 & 0.7 & 0.0 & 0.6 & 0.0 & 0.0 & 0.0 & 0.4 & 0.0 & 0.3 & 0.0 & 1.1 \\
\hline
\end{tabular}

$V_{C E(\text { Sat })}=V_{F}=2.5 \mathrm{~V}(0.25 \%)$ 程度の電圧降下が想定さ れる。したがって，順方向電圧降下の影響はミニモデルに 比べて格段に小さくなる。図 18 は， $v_{C}=70 \mathrm{~V}$ の場合にス ケールダウンし, $V_{C E(S a t)}=V_{F}=0.17 \mathrm{~V}(0.25 \%)$ とした場 合のシミュレーション結果を示す。(シミュレーション II )。 電圧降下によるひずみが大幅に減少している。このことか ら，6.6kV STATCOM では順方向電圧降下の影響は無視で きる。

表 2 は各次高調波含有率およびTHDをまとめたもので ある。THDは40次成分までを考慮し，DFT 演算により算 出した。サンプリング周期は $10 \mu \mathrm{s}$ である。IGBT/ダイオー ドの電圧降下は特に 5 次， 7 次高調波を多く発生するため THD は悪化する。「実験」と「シミュレーション I」では， この影響が顕著に表れている。また，「実験」では非論理高 調波の 2 次， 3 次高調波も $1 \%$ 程度含まれている。この要 因としては，電源電圧の不平衡や回路素子のばらつきのた めに，実験システムは完全な三相平衡回路とはならないた めである。シミュレーションでは電源と回路ともに完全な 三相平衡を仮定しているため，この影響は再現されていな い。一方，「シミュレーション II」のように電圧降下が無視 できるような場合には THD は $1.1 \%$ だ低減できる。した がって，実システムの非論理高調波の割合をミニモデルと 同程度と仮定すると，系統ガイドラインを十分満足できる と考えられる。

\section{6. むすび}

本論文では， $6.6 \mathrm{kV}$ 配電系統用カスケード PWM STATCOM の実用化において必要不可欠となる, 直流コンデンサ 電圧のバランス制御法を論じた。さらに，三相 $200 \mathrm{~V} \mathrm{10kVA}$ のミニモデルを設計・製作し，検証実験を行った。相間バラ ンス制御と段間バランス制御を併用することによって定常 運転時のみならず，起動時や過渡時においても直流コンデ ンサ電圧の不均一を抑制し，かつ無効電力を制御できるこ とを実証した。また，電流波形の 5 次， 7 次高調波は IGBT/ ダイオードの順方向電圧降下に起因し，6.6 kV STATCOM では電源や回路の不平衡による非論理高調波の影響を考慮 しても，系統ガイドラインを十分に満足できる可能性を明 らかにした。

本研究を進めるに当たり，ご協力いただきました東京工 業大学大学院理工学研究科電気電子工学専攻三宅靖彦氏 (現 四国電力勤務）に厚くお礼申し上げます。

(平成 18 年 7 月 12 日受付，平成 18 年 11 月 21 日再受付)

\section{文献}

(1) T. Ohnishi: "Multiple single-phase PWM inverter by means of combination control", IEEJ Trans. Ind. Appl., Vol.115, No.1, pp.63-69 (1995) (in Japanese)

大西徳生：「組み合わせ制御方式単相多重化 PWM インバータ」, 電 学論 D, 115, 1, pp.63-69 (1995)

(2) J.S. Lai and F.Z. Peng: "Multilevel Converters-A New Breed of Power Converters", IEEE Trans. Ind. Appl., Vol.32, No.3, pp.509-517 (1996)

(3) F.Z. Peng, J.S. Lai, J.W. McKeever, and J. VanCoevering: "A Multilevel Voltage-Source Inverter with Separate DC Sources for Static Var Generation”, IEEE Trans. Ind. Appl., Vol.32, No.5, pp.1130-1138 (1996)

(4) P. Hammond: "A new approach to enhance power quality for mediumvoltage ac drives", IEEE Trans. Ind. Appl., Vol.33, No.1, pp.202-208 (1997)

5 ) F.Z. Peng and J.S. Lai: "Dynamic performance and control of a static var generator using multilevel inverters", IEEE Trans. Ind. Appl., Vol.33, No.3, pp.748-755 (1998)

(6) F.Z. Peng, J.W. McKeever, and D.J. Adams: "A power line conditioner using multilevel inverters for distribution systems", IEEE Trans. Ind. Appl., Vol.34, No.6, pp.1293-1298 (1998)

( 7 ) J.D. Ainsworth, M. Davies, P.J. Hitz, K.E. Owen, and D.R. Trainer: "Static var compensator (STATCOM) based on single-phase chain circuit converters", IEE Proc.-Gener. Transm. Distrib., Vol.145, No.4, pp.381-386 (1998)

(8) L.M. Tolbert, F.Z. Peng, and T.G. Habetler: "Multilevel converters for large electric drives", IEEE Trans. Ind. Appl., Vol.35, No.1, pp.36-44 (1999)

(9) Y. Liang and C.O. Nwankpa: "A new type of STATCOM based on cascading voltage-source inverters with phase-shifted unipolar SPWM", IEEE Trans. Ind. Appl., Vol.35, No.5, pp.1118-1123 (1999)

(10) M.D. Manjrekar, P.K. Steimer, and T.A. Lipo: "Hybrid multilevel power conversion system: A competitive solution for high-power applications", IEEE Trans. Ind. Appl., Vol.36, No.3, pp.834-841 (2000)

11) L.M. Tolbert, F.Z. Peng, and T.G. Habetler: "Multilevel PWM methods at low modulation indices", IEEE Trans. Power Electronics, Vol.15, No.4, pp.719-725 (2000)

12) J. Rodriguez, J.S. Lai, and F.Z. Peng: "Multilevel Inverters: a survey of topologies, controls, and applications", IEEE Trans. Ind. Electron., Vol.49, No.4, pp.724-738 (2002)

13) M. Lopez, L. Moran, J. Espinoza, and J. Dixon: "Performance analysis of a hybrid asymmetric multilevel inverter for high-voltage active power filter applications", in Conf. Rec. IEEE-IES IECON, pp.1050-1055 (2003)

(14) A.M. Massound, S.J. Finney, and B.W. Williams: "Seven-level active power filter", in Conf. Rec. IEEE International Conference on Harmonics and Quality of Power, pp.136-141 (2004)

(15) L.A. Silva, S.P. Pimentel, and J.A. Pomilio: "Nineteen-level active filter system using asymmetrical cascaded converter with dc voltage control", in Conf. Rec. IEEE-PELS PESC, pp.303-308 (2005)

(16) K. Fujii, U. Schwarzer, and R.W. De Doncker: "Comparison of hard-switched multi-level inverter topologies for STATCOM by lossimplemented simulation and cost estimation", in Conf. Rec. IEEE-PELS PESC, pp.340-346 (2005)

(17) L.A. Silva, S.P. Pimentel, and J.A. Pomilio: "Analysis and proposal of capacitor voltage control for an asymmetrical cascaded inverter", in Conf. Rec. IEEE-PELS PESC, pp.809-815 (2005)

(18) D. Soto and T.C. Green: "A dc link capacitor voltage control strategy of a PWM cascade STATCOM", in Conf. Rec. IEEE-PELS PESC, pp.2251-2256 (2005)

(19) N. Hatano, Y. Kishida, and A. Iwata: "STATCOM using the new concept of inverter system with Controlled Gradational Voltage", JIASC 2005, Vol.1, R1-2, 1-9, pp.89-92 (2005) (in Japanese)

羽田野伸彦・岸田行盛・岩田明彦：「階調制御型変換器を用いた自励 式無効電力補償装置」, 平 17 電気学会産業応用部門大会, Vol.1, R1-2, 1-9, pp.89-92 (2005)

20) K. Fujii, R.W. De Doncker, and S. Konishi: "A novel dc-link voltage control of PWM-switched cascade cell multi-level inverter applied to STATCOM", 
in Conf. Rec. IEEE-IAS Ann. Meeting, pp.961-967 (2005)

(21) A. Nabae, I. Takahashi, and H. Akagi: "A new neutral-point-clamped PWM inverter", IEEE Trans. Ind. Appl., Vol.17, No.5, pp.518-523 (1981)

(22) H. Akagi, Y. Kanazawa, and A. Nabae: "Instantaneous reactive power compensators comprising switching devices without energy storage components", IEEE Trans. Ind. Appl., Vol.20, No.3, pp.625-630 (1984)

(23) H. Fujita, S. Tominaga, and H. Akagi: "Analysis and design of a dc voltagecontrolled static var compensator using quad-series voltage-source inverters", IEEE Trans. Ind. Appl., Vol.32, No.4, pp.970-978 (1996)

(24) 電気学会・半導体電力変換システム調査専門委員会：「パワーエレ クトロニクス回路」,オーム社, pp.74-90 (2000-11)

\section{吉 井}

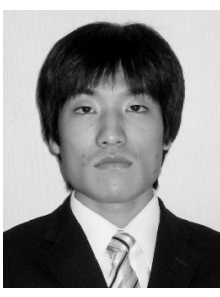

剣 （学生員） 1983 年 4 月 7 日生。 2006 年 3 月東京 工業大学電気電子工学科卒業。同年 4 月, 東京工 業大学大学院理工学研究科電気電子工学専攻修士 課程入学, 現在に至る。カスケード变換器に関す る研究に従事。

井上重 徳

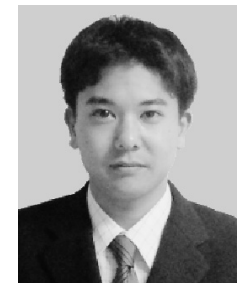

(学生員) 1979 年 1 月 29 日生。 2004 年 3 月東 京都立大学大学院工学研究科修士課程電気工学専 攻修了。同年 3 月, 東京工業大学大学院理工学研 究科電気電子工学専攻博士後期課程入学, 現在に 至る。次世代半導体電力変換回路に関する研究に 従事。
赤 木 泰 文 （正員） 1951 年 8 月 19 日生。1979 年 3 月東京工

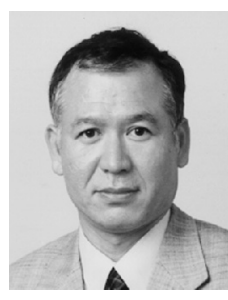
業大学大学院電気工学専攻博士課程修了。工学博 士。長岡技術科学大学, 岡山大学を経て, 2000 年 1 月東京工業大学教授。パワーエレクトロニクスの 研究に従事。電気学会論文賞を 4 回, IEEE Transactions Prize Paper Award を 4 回受賞。1996 年 IEEE Felow。2001 年 IEEE William E. Newell Power Elecronics Award。2004 年 IEEE Industry Applications Society Outstanding Achievement Award。2006 年文部科学大臣表彰科 学技術賞 (研究部門)。 